\title{
Dominant-Negative DISC1 Alters the Dopaminergic Modulation of Inhibitory Interneurons in the Mouse Prefrontal Cortex
}

\author{
Ross A. Cardarellia Rolicia Martin ${ }^{b}$ Hanna Jaaro-Peled ${ }^{d}$ Akira Sawa $^{d}$ \\ Elizabeth M. Powell ${ }^{b, c}$ Patricio O'Donnell ${ }^{a-c}$ \\ a Program in Neuroscience, University of Maryland Medical School, Baltimore, MD, USA; ${ }^{\mathrm{b}}$ Department of Anatomy \\ and Neurobiology, University of Maryland Medical School, Baltimore, MD, USA; ' Department of Psychiatry, \\ University of Maryland Medical School, Baltimore, MD, USA; ${ }^{d}$ Department of Psychiatry, The Johns Hopkins \\ University School of Medicine, Baltimore, MD, USA
}

\section{Keywords}

GABA · Parvalbumin · Schizophrenia · Interneurons ·

Dopamine

\begin{abstract}
A truncated disrupted in schizophrenia 1 (Disc1) gene increases the risk of psychiatric disorders, probably affecting cortical interneurons. Here, we sought to determine whether this cell population is affected in mice carrying a truncated (Disc1) allele (DN-DISC1). We utilized whole cell recordings to assess electrophysiological properties and modulation by dopamine (DA) in two classes of interneurons: fast-spiking (FS) and low threshold-spiking (LTS) interneurons in wildtype and DN-DISC1 mice. In DN-DISC1 mice, FS interneurons, but not LTS interneurons, exhibited altered action potentials. Further, the perineuronal nets that surround FS interneurons exhibited abnormal morphology in DN-DISC1 mice, and the DA modulation of this cell type was altered in DNDISC1 mice. We conclude that early-life manipulation of a gene associated with risk of psychiatric disease can result in dysfunction, but not loss, of specific GABAergic interneurons. The resulting alteration of excitatory-inhibitory balance is a critical element in DISC1 pathophysiology.
\end{abstract}

(c) 2018 S. Karger AG, Basel

\section{KARGER}

(c) 2018 S. Karger AG, Basel

E-Mail karger@karger.com

www.karger.com/mnp

\section{Introduction}

A widely held hypothesis of schizophrenia pathophysiology posits that cortical circuits are in a state of altered excitation-inhibition balance characterized by loss of GABA interneuron function [1-4]. This hypothesis has been driven by postmortem studies revealing altered interneuron-associated markers in brains of patients [5-12]. Several developmental, pharmacological, and genetic manipulations yield loss of interneuron markers such as expression of the calcium-binding protein parvalbumin (PV) in a distinct subset of neurons [13-26], and all these manipulations yield adult animals with a range of behavioral deficits [27]. These data suggest that early-life disruption can lead to long-lasting changes in PV interneurons, supporting the notion that abnormal interneurons can drive altered excitation/inhibition balance.

While developmental models are useful tools to explore possible pathophysiological scenarios, their link to etiological factors is poor. There are very few conditions in which a rare gene variation confers high penetrance for schizophrenia and related disorders; these conditions include 22q11 translocations and the translocation observed in a Scottish family that allowed identification of 
the disrupted in schizophrenia 1 (Disc1) gene. Disc1 is a gene found at the breakpoint of a chromosomal translocation in a Scottish family with an increased risk of developing major psychiatric illnesses, including schizophrenia $[28,29]$. DISC1 is a scaffolding protein with multiple roles, such as cell fate control by switching from progenitor cell proliferation to neural differentiation, intracellular transport, and synaptic regulation [30-37]. The truncated segment encoded by the chromosomal alteration acts as a dominant-negative protein when expressed in the cell [38], here abbreviated as DN-DISC1. By tying expression to the $\alpha C a M K I I$ promoter, cerebral cortical expression is restricted to pyramidal neurons (PYR) with an onset in the first postnatal week. Altering DISC1 affects excitation/inhibition balance in the adult prefrontal cortex (PFC) of different DISC1 mouse models [39-41], desynchronized neurotransmitter release in rats with in utero RNAi knockdown of Disc1 [42], and decreased PV levels in a transgenic model expressing DN-DISC1 [43]. The DN-DISC1 model is therefore a useful tool for assessing the role of DISC1 in adult interneuron physiology.

Dopamine (DA) is critical for proper function of the PFC by modulating the balance between excitation and inhibition. The DA effects on PFC physiology mature during adolescence in rats [44], and one of the most dramatic periadolescent changes is the acquisition of a strong excitatory effect of $\mathrm{D} 2$ receptor activation onto a subset of cerebral cortical GABAergic interneurons [4447]. It is likely that this protracted maturation contributes to proper adult control of excitation-inhibition balance in PFC circuits. The PFC contains several different types of inhibitory interneurons $[48,49]$. Two of the most studied classes of inhibitory cells provide complementary inhibition to layer 5 pyramidal cells through targeting input (dendritic) and output (somatic) domains. Fast-spiking (FS) interneurons express PV [50] and innervate the soma and axon initial segment of pyramidal cells [51]. Strong inhibition from PV-expressing cells sharpens the integration window of inputs into pyramidal cells [52-54], shaping the amount and timing of their output. FS interneuron activity promotes gamma oscillations, which in turn have been linked to information processing [55], and direct optogenetic stimulation can induce these rhythms in vivo [56]. While in juvenile rats FS interneuron D1 receptors are excitatory and D2 receptors are mildly inhibitory $[44,57,58]$, in adult rats both D1 and D2 receptor activation causes a strong increase in excitability. Somatostatin-expressing low threshold-spiking (LTS) interneurons form a comple- mentary inhibitory subpopulation in the cortex [50], with a prominent axon ascending to the distal pyramidal cell apical dendrites. Dendritic GABAergic innervation limits the spread of back-propagating action potentials, and LTS interneurons have been shown to play a role in both recurrent and disynaptic inhibition between pyramidal cells $[59,60]$. It is not currently known whether the LTS population is modulated by DA receptor signaling.

Both LTS and FS interneurons may be involved in the pathophysiology of schizophrenia, as suggested by postmortem studies [61-63]. With the growth of genetic mouse manipulations to test the neurobiological impact of genes conferring risk of schizophrenia, it is important to determine the nature of D2 modulation of interneurons in these animals. The adult animals, D2-mediated excitation of FS interneurons is impaired in diverse developmental manipulations that result in adult animals exhibiting phenomena relevant to schizophrenia, including the neonatal ventral hippocampal lesion rat developmental model [20, 64]. In utero gene knockdown of Disc 1 resulted in diminished attenuation of excitatory postsynaptic potentials by a $\mathrm{D} 2$ agonist, a modulation dependent on D2 recruitment of GABA interneurons [65]. Here, we explored whether FS and LTS interneurons respond differently to D2 agonists in slices from adult control mice and whether the adult D2 modulation of these cells is affected in the PFC of DN-DISC1 mice.

\section{Methods}

Animals

All procedures followed the United States Public Health Service Guide for the Care and Use of Laboratory Animals and were approved by the University of Maryland Institutional Animal Care Committee. Adult (>60 days old) male wild-type C57BL/6 mice were purchased from Charles River or were wild-type littermates of DN-DISC1 mice. DN-DISC1 mice were bred in-house by crossing DN male and same-background Charles River control female mice. Animals were kept in a temperature- and humidity-controlled environment with a $12-\mathrm{h}$ on/12-h off light cycle. Food and water were available ad libitum.

\section{Slice Preparation}

Following an overdose with the anesthetic chloral hydrate (8\% solution i.p.), animals were transcardially perfused with oxygenated $\left(95 \% \mathrm{O}_{2}, 5 \% \mathrm{CO}_{2}\right)$ ice-cold slicing artificial cerebrospinal fluid containing $125 \mathrm{~mm}$ sodium chloride, $25 \mathrm{~mm}$ sodium bicarbonate, $10 \mathrm{~mm}$ glucose, $3.5 \mathrm{~mm}$ potassium chloride, $1.25 \mathrm{~mm}$ monobasic sodium phosphate, $0.08 \mathrm{mM}$ sodium metabisulfite, $0.1 \mathrm{mM}$ calcium chloride, and $3 \mathrm{~mm}$ magnesium chloride, pH 7.45, osmolarity 290 mOsm. Following decapita- 
tion, the brain was removed and blocks containing the PFC were dissected on ice. Coronal slices $(300 \mu \mathrm{m})$ containing the medial PFC were sectioned on a vibratome (Pelco 102, Ted Pella) and incubated in $33^{\circ} \mathrm{C}$ slicing aCSF for at least $1 \mathrm{~h}$ prior to recordings.

\section{Slice Electrophysiology}

PFC slices were submerged (RC-22, Warner Instruments) and perfused at $2 \mathrm{~mL} / \mathrm{min}$ with oxygenated recording aCSF, in which the concentration of calcium chloride was $2 \mathrm{mM}$ and magnesium chloride was lowered to $1 \mathrm{mM}$. All experiments were conducted at $33^{\circ} \mathrm{C}$. Drugs were prepared each day and diluted to the final concentration in oxygenated aCSF. Cells in layer 5 of the medial PFC were visually identified by infrared differential interference contrast video microscopy with a $40 \times$ water immersion objective. Images were captured by a digital CCD camera and displayed on a monitor to visually target recordings. Pipettes for intracellular recording (6-10 $\mathrm{M} \Omega$ ) were filled with internal solution containing $115 \mathrm{~mm}$ potassium gluconate, $10 \mathrm{mM}$ HEPES, $20 \mathrm{~mm}$ potassium chloride, $2 \mathrm{mM}$ magnesium chloride, $2 \mathrm{mM}$ adenosine triphosphate (magnesium salt), $2 \mathrm{mM}$ adenosine triphosphate (disodium salt), and $0.3 \mathrm{~mm}$ guanosine triphosphate (lithium salt), $\mathrm{pH}$ 7.3, osmolarity $280 \mathrm{mOsm}$. Neurobiotin $(0.125 \%)$ was also dissolved in the internal solution for post hoc identification of recorded neurons. Intracellular whole-cell recordings were obtained through a headstage (CV7, Molecular Devices) and digitized (Digidata 1322A, Molecular Devices). Signals were acquired at a sampling rate of $20 \mathrm{KHz}$ with Axoscope 9.0, low-pass filtered at $10 \mathrm{kHz}$, and passed through a $60-\mathrm{Hz}$ noise attenuation system to remove AC line noise (Hum Bug, Quest Scientific). Pipette capacitance and resistance were measured in the recording solution and subtracted; liquid junction potential was not corrected. Quinpirole hydrochloride was purchased from Tocris Bioscience.

\section{Experiment}

Changes in excitability of cells were assessed by changes in response to a custom-designed excitability protocol (MATLAB). This protocol delivers three current pulses in succession every $30 \mathrm{~s}$ : a small negative current to monitor changes in input resistance, a positive square pulse which was initially set to elicit several action potentials during the baseline period, allowing for detection of excitation or inhibition, and a positive-going ramp current (1 s duration) with a maximum amplitude set to $110 \%$ of the square pulse to determine rheobase. After a baseline period including 5 min to determine baseline excitability, the high-affinity D2/D3 receptor agonist quinpirole was applied in the external solution for $5 \mathrm{~min}$ and then washed out, similar to previously published data [44].

\section{Analysis}

Action potential measurements were quantified at rheobase. Threshold was manually determined as the inflection point of the upstroke of the action potential. Amplitude, afterhyperpolarization (AHP) time, and amplitude were all measured relative to threshold. The duration of the action potential was measured as width at half-amplitude. Input resistance was measured as the slope within the linear portion of the voltage response to a series of negative current pulses. Quinpirole responses were quantified during the last 6 sweeps ( $3 \mathrm{~min}$ ) of drug application and compared to the average of the 10-sweep baseline period. Data are presented as mean \pm standard deviation. Significance was determined based on $\alpha=0.05$ using Student $t$ tests.

\section{Results}

FS and LTS interneuron cells exhibited distinct electrophysiological profiles in recordings from adult $(>60$ days old) PFC. Most FS interneurons showed an inconsistent "stuttering" firing pattern in response to nearthreshold intracellular current injection and a steep, discontinuous increase in firing to increasing current intensities, as reported previously $[50,66,67]$. The LTS action potential count increased linearly to ascending suprathreshold current intensities and required much lower current intensities to evoke action potentials compared to FS interneurons. In some cases, LTS interneurons fired rebound action potentials at the termination of hyperpolarizing current steps. In some cells, neurobiotin staining was overlaid with GABA or GABA and Wisteria floribunda agglutinin, a marker for perineuronal nets (PNNs) which selectively form around PV-containing interneurons to confirm cell identity.

The action potential properties and intrinsic excitability of FS interneurons from adult DN-DISC1 mice were dramatically different from those in control animals ( $n=16$ control cells, $n=11$ DN-DISC 1 cells). There was a nonsignificant trend towards a depolarized resting membrane potential in DN-DISC1 (control: $-68.2 \pm$ $6.0 \mathrm{mV}$; DN-DISC1: $-63.1 \pm 7.2 \mathrm{mV} ; t=1.96, p=0.062)$, but input resistance (control: $260 \pm 119 \mathrm{M} \Omega$; DN-DISC1: $272 \pm 107 \mathrm{M} \Omega ; t=0.26$, ns) was not different between the two genotypes. Action potentials in DN-DISC1 FS interneurons (Fig. 1a) were of longer duration (Fig. 1b; control: $1.1 \pm 0.2 \mathrm{~ms}$; DN-DISC1: $1.5 \pm 0.4 \mathrm{~ms} ; t=3.64$, $p=0.001$ ), and the prominent AHP, a characteristic of FS interneurons, was smaller in DN-DISC1 FS interneurons (Fig. 1c; control: $19.3 \pm 3.9 \mathrm{mV}$; DN-DISC1: $13.4 \pm$ $4.6 \mathrm{mV} ; t=3.52, p=0.002)$. Action potential threshold did not differ between control and DN-DISC1 animals (control: $-40.9 \pm 5.1 \mathrm{mV}$; DN-DISC1: $-36.4 \pm 6.8 \mathrm{mV}$; $t=1.91, p=0.068)$, and neither did action potential amplitude (control: $52.9 \pm 9.8 \mathrm{mV}$; DN-DISC1: $51.3 \pm$ $13.9 \mathrm{mV} ; t=0.34$, ns). To examine inhibitory circuitry maturation surrounding FS interneurons, we assessed the PNNs with Wisteria floribunda agglutinin. FS interneurons in DN-DISC1 were surrounded by PNNs, but the nets were spidery in appearance and less coalesced 
around FS interneuron somata (Fig. 1d). The minimum current intensity required to evoke an action potential (rheobase) was modestly but significantly lower in DNDISC1 FS interneurons (control: $64.75 \pm 48.44 \mathrm{pA}$; DNDISC1: $27.7 \pm 31.8 \mathrm{pA} ; t=2.14, p=0.043)$. The data indicate that FS interneurons from DN-DISC1 mice have altered electrophysiological properties and exhibit a different PNN morphology.

During the adolescent critical period, PFC FS interneurons acquire a D2 modulation that is different from that of preadolescent neurons $[44,46]$. We tested whether this maturation is affected in DN-DISC1 mice. In FS interneurons from control animals, bath application of the D2 agonist quinpirole $(1.0-2.0 \mu \mathrm{M})$ consistently increased the number of action potentials evoked by a constant-current depolarizing pulse (Fig. 2a, c, d) (aCSF: $5.6 \pm 2.0$; quinpirole: $9.7 \pm 5.3 ; t=2.94, p=0.026 ; n=7$ ). Quinpirole did not alter resting membrane potential (aCSF: $-67.4 \pm 6.9 \mathrm{mV}$; quinpirole: $-66.6 \pm 6.4 \mathrm{mV}$; $t=$ 1.35 , ns) or input resistance (aCSF: $319 \pm 167 \mathrm{M} \Omega$; quinpirole: $331 \pm 170 \mathrm{M} \Omega$; $t=1.98$, ns), but the action potential increase was accompanied by a decrease in rheobase (aCSF: $77.1 \pm 60.2 \mathrm{pA}$; quinpirole: $66.0 \pm 50.8 \mathrm{pA} ; t=$ $2.69, p=0.043)$. The latency to first action potential was also reduced by quinpirole in some cells, but this result did not reach statistical significance in the group data (aCSF: $80.9 \pm 86.5 \mathrm{~ms}$; quinpirole: $34.5 \pm 29.5 \mathrm{~ms}$; $t=$ $2.05, p=0.086$ ). Unlike in control FS interneurons, quinpirole did not result in increased action potential firing in FS interneurons from DN-DISC1 animals (Fig. 2b, e, f) (aCSF: $5.4 \pm 2.7$; quinpirole: $6.1 \pm 5.0 ; t=0.52$, ns). Confirming a lack of excitation, the latency to first spike (aCSF: $99.0 \pm 126.8 \mathrm{~ms}$; quinpirole: $91.5 \pm 125.9 \mathrm{~ms} ; t=$ $0.68, \mathrm{~ns})$ and rheobase (aCSF: $46.5 \pm 13.9 \mathrm{pA}$; quinpirole: $48.4 \pm 11.4 \mathrm{pA} ; t=1.03$, ns) were also unaffected by D2 receptor activation. As in control FS interneurons, resting membrane potential (aCSF: $-62.7 \pm 6.8 \mathrm{mV}$; quinpirole: $-62.6 \pm 7.2 \mathrm{mV} ; t=0.15$, ns) and input resistance (aCSF: $323 \pm 156 \mathrm{M} \Omega$; quinpirole: $321 \pm 155 \mathrm{M} \Omega$; $t=$ 0.33 , ns) were unaffected. The lack of normal adult upregulation in evoked firing by activation of D2 receptors, along with the altered electrophysiological phenotype, suggests a functional impairment of FS interneurons in DN-DISC1 animals.

In contrast to the abnormalities observed in FS interneurons from DN-DISC1 mice, LTS interneurons did not show obvious electrophysiological abnormalities (15 control LTS interneurons, 18 DN-DISC1 LTS interneurons). There were no changes in LTS membrane potential (control: $-61.5 \pm 6.9 \mathrm{mV}$; DN-DISC1: $-61.7 \pm 7.3 \mathrm{mV}$;

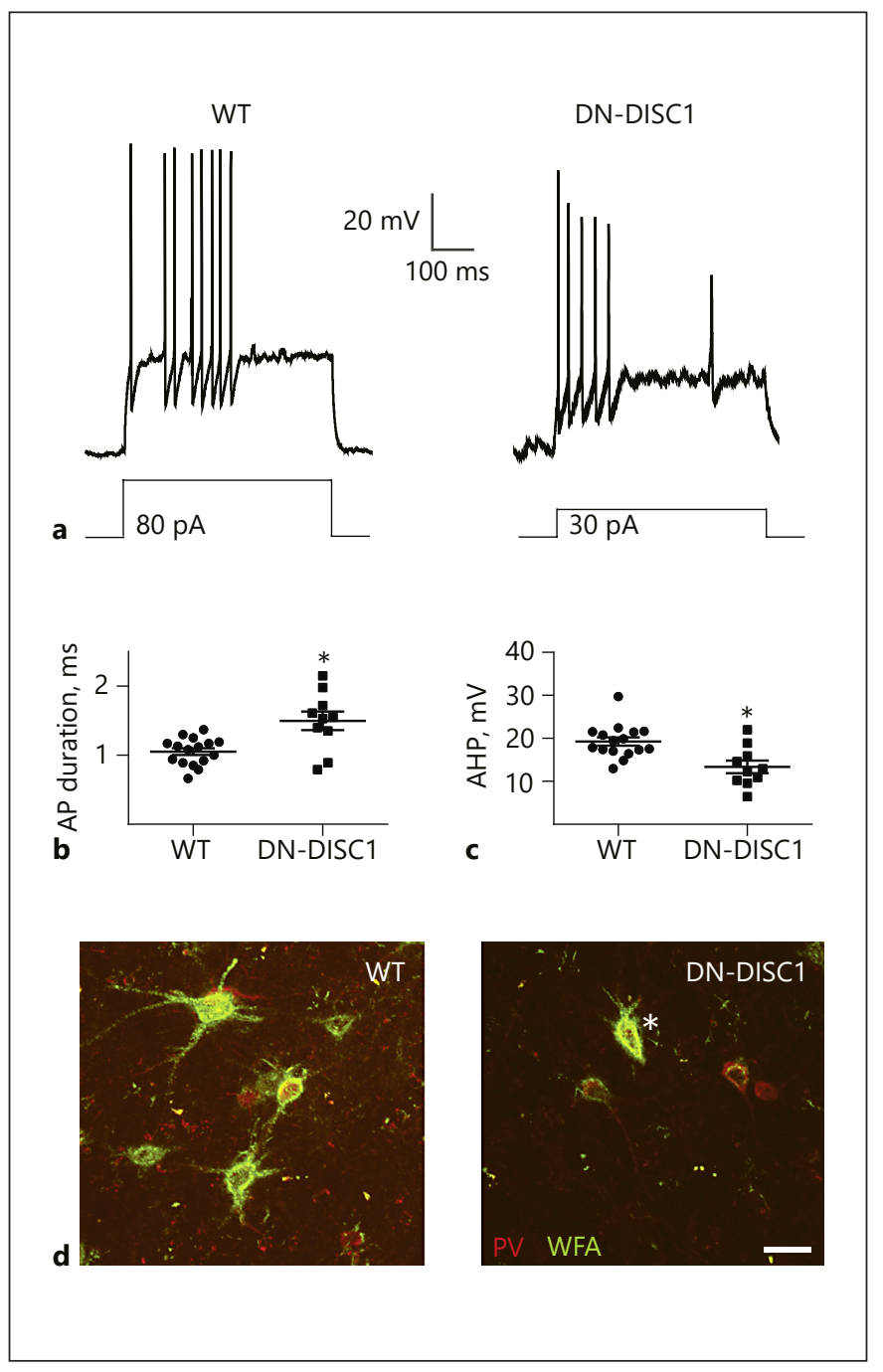

Fig. 1. Whole-cell patch clamp recordings from adult FS interneurons in control and DN-DISC1 medial PFC. a Representative responses to depolarizing somatic current pulses $(500 \mathrm{~ms}$, set to threshold current for each neuron). b, c Population data showing increased action potential duration at half-width in DN-DISC1 (b) and reduction in the prominent AHP normally observed in these cells (c). All data are mean \pm standard deviation. ${ }^{*} p<0.05$. d Overlay of immunofluorescence of PV (red) and Wisteria floribunda agglutinin (green) in WT medial PFC shows tightly coalesced perineuronal net structures around PV interneurons (left), whereas DN-DISC1 medial PFC shows net structures with a spidery, looser organization (right). Several cells surrounded with Wisteria floribunda agglutinin immunoreactivity do not demonstrate measureable PV immunoreactivity (example marked with asterisk). Scale bar, $50 \mu \mathrm{m}$. AHP, afterhyperpolarization; AP, action potential; FS, fast-spiking; PFC, prefrontal cortex; PV, parvalbumin; WT, wild-type. 
Fig. 2. a Response to D2 agonists in WT FS interneurons. Representative whole-cell recordings of increased AP count are shown in response to quinpirole $(1-2 \mu \mathrm{M})$. Somatic current injection (500 ms) was set for each cell and held at a constant amplitude throughout each experiment. b Whole-cell recording example of a DNDISC1 FS interneuron which did not show increased AP count to quinpirole application. c Progressive and sustained increase in AP count of WT FS interneurons in response to D2 agonists (in gray). All data are mean \pm standard deviation. d Group data indicating average AP count (6 trials) to depolarizing current before and during quinpirole administration in WT FS interneurons. ${ }^{*} p<0.05$. e Quinpirole $(1-2 \mu \mathrm{M})$ did not reliably increase the number of evoked APs in FS interneurons from DNDISC1 medial PFC through the course of the experiment (D2 agonist application indicated in gray). All data are mean \pm standard deviation. $f$ Group data indicating average AP count (6 trials) to depolarizing current before and during quinpirole administration in DN-DISC1 FS interneurons. AP, action potential; FS, fast-spiking; WT, wild-type.
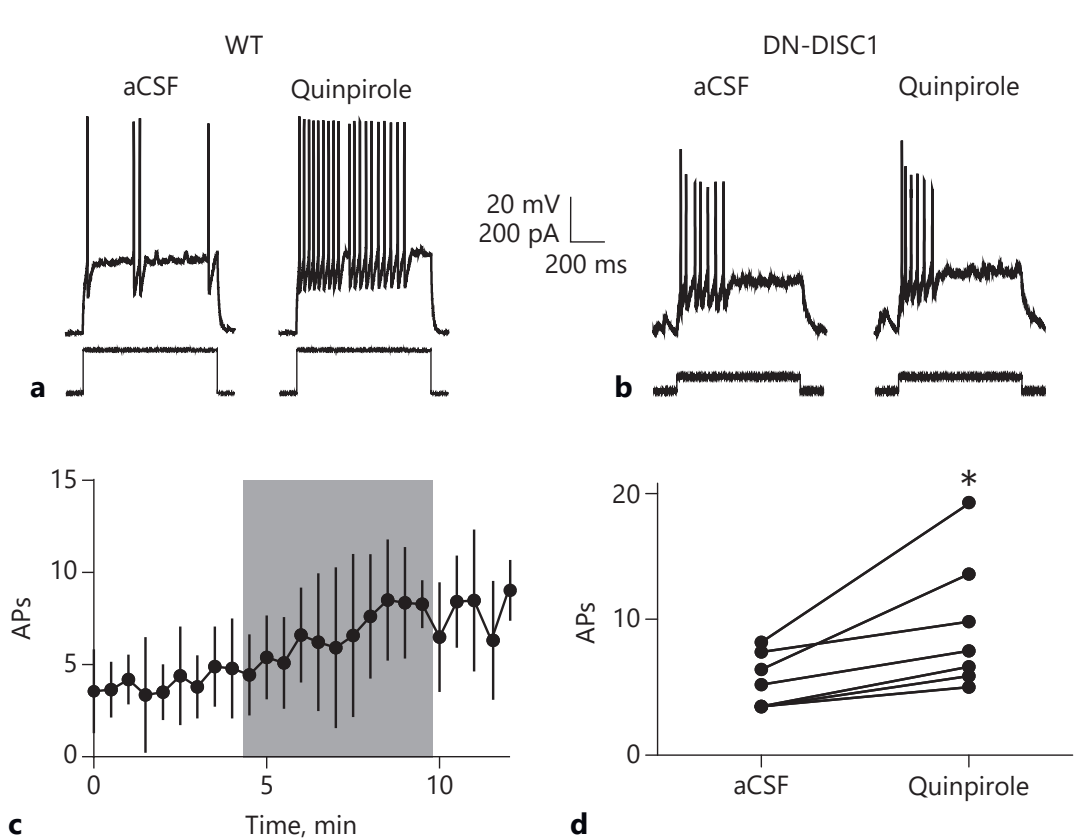

Time, $\min$
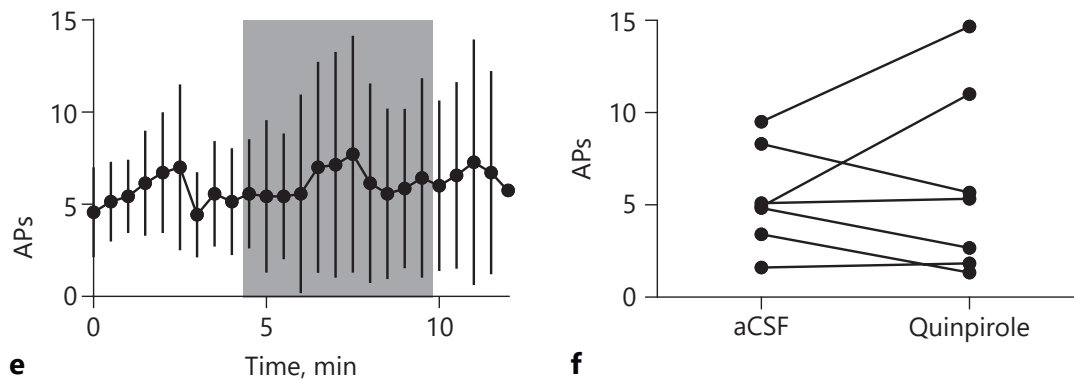

$t=0.08, \mathrm{~ns})$, and other passive membrane properties including input resistance (control: $378 \pm 70 \mathrm{M} \Omega$; DNDISC1: $427 \pm 219 \mathrm{M} \Omega ; t=0.78, \mathrm{~ns})$ and rheobase were similar between the two genotypes (control: $10.8 \pm$ 10.9 pA; DN-DISC1: $14.4 \pm 13.4 \mathrm{pA} ; t=0.90$, ns). Action potential characteristics including threshold (control: $-42.1 \pm 2.8 \mathrm{mV}$; DN-DISC1: $-41.8 \pm 3.4 \mathrm{mV} ; t=0.33, \mathrm{~ns}$ ), amplitude (control: $71.2 \pm 8.8 \mathrm{mV}$; DN-DISC1: $68.9 \pm$ $7.1 \mathrm{mV} ; t=0.84, \mathrm{~ns}$ ), duration (control: $1.8 \pm 0.4 \mathrm{~ms}$; DNDISC1: $1.9 \pm 0.4 \mathrm{~ms} ; t=0.79$, ns), and AHP amplitude (control: $10.9 \pm 3.4 \mathrm{mV}$; DN-DISC1: $9.3 \pm 3.0 \mathrm{mV}$; $t=$ 1.52 , ns) were all similar between LTS cells of the two genotypes.

LTS cells $(n=11)$ from control animals did not show a consistent response to the D2 agonist (Fig. 3a), respond- ing with a similar number of action potentials throughout and after drug application (Fig. 3b). Quinpirole (1.0$2.0 \mu \mathrm{M})$ did not change the number of action potentials evoked by somatic current injection (Fig. $3 c ; 6.4 \pm 2.1$ to $5.9 \pm 2.1 ; t=1.16$, ns), with latency to first action potential (aCSF: $54.9 \pm 40.1 \mathrm{~ms}$; quinpirole: $53.1 \pm 45.8 \mathrm{~ms} ; t=0.22$, ns) and rheobase (aCSF: $12.9 \pm 8.8 \mathrm{pA}$; quinpirole: $11.7 \pm$ $8.2 \mathrm{pA} ; t=1.27$, ns) also unchanged. Subthreshold measures including membrane potential and input resistance were not affected by quinpirole application either. DNDISC1 LTS did not respond to bath application of quinpirole (data not shown).

Since DN-DISC1 is expressed under the $\alpha$ CaMKII promoter, we examined the intrinsic excitability and action potential characteristics of PYR. In whole-cell re- 
cordings, PYR exhibited low input resistance, a small AHP, and spike frequency attenuation with or without an initial doublet of action potentials when driven with intracellular current pulses. In cells where the neurobiotin fill was recovered and visualized, pyramidal cells were identified by their morphology, including an apical dendrite reaching towards the pial surface. The intrinsic excitability of PYR was not altered in DN-DISC1 mice $(n=$ 58 control, $n=40$ DN-DISC1). Resting membrane potential (control: $-67.8 \pm 4.7 \mathrm{mV}$; DN-DISC1: $-67.5 \pm 5.8 \mathrm{mV}$; $t=0.26, \mathrm{~ns}$ ) and input resistance (control: $153 \pm 47 \mathrm{M} \Omega$; DN-DISC1: $164 \pm 57 \mathrm{M} \Omega ; t=0.97$, ns) were similar between genotypes, as was rheobase (control: $112.9 \pm$ 45.8 pA; DN-DISC1: $105.1 \pm 45.6 \mathrm{pA} ; t=0.83$, ns). PYR action potential characteristics were similarly unaffected in DN-DISC1 animals, with threshold (control: $34.7 \pm$ $4.5 \mathrm{mV}$; DN-DISC1: $36.8 \pm 5.8 \mathrm{mV} ; t=1.98$, ns), amplitude (control: $67.9 \pm 8.5 \mathrm{mV}$; DN-DISC1: $71.0 \pm 9.6 \mathrm{mV}$; $t=1.65$, ns), and half-width (control: $2.18 \pm 0.5 \mathrm{~ms}$; DNDISC1: $2.34 \pm 0.6 \mathrm{~ms} ; t=1.38, \mathrm{~ns})$.

In a subset of PYR cells, each genotype was tested for changes in its modulation by quinpirole $(1.0-2.0 \mu \mathrm{M})$. PYR did not show any changes in excitability in response to quinpirole application as reflected in action potential count in control PYR $(n=11$; aCSF: $4.7 \pm 1.1$; quinpirole: $4.4 \pm 1.4 ; t=0.87$, ns) or PYR from DN-DISC1 mice $(n=$ 14; aCSF: $5.1 \pm 1.0$; quinpirole: $5.0 \pm 1.8 ; t=0.17$, ns). These data indicate that expression of DN-DISC1 does not affect PYR excitability or their modulation by D2 agonists.

\section{Discussion}

FS and LTS interneurons were separable from each other and from pyramidal cells based on their basic membrane properties and action potential characteristics. This separation was preserved in slices from DNDISC1 mice, allowing comparison of their electrophysiological phenotype and their modulation by DA. In wildtype mice, the D2 agonist quinpirole elicited a sustained increase in action potential firing in FS interneurons, but not LTS interneurons, similar to what has been reported in rats. Although in rats some non-FS interneurons can also be excited by a D2 agonist, a selective characterization of LTS interneurons was not attempted. Here, we showed that mouse LTS interneurons are not modulated by quinpirole. In DN-DISC1 mice, the excitatory effect of quinpirole on FS interneurons was absent, along with abnormal morphology of PNNs. While there was some

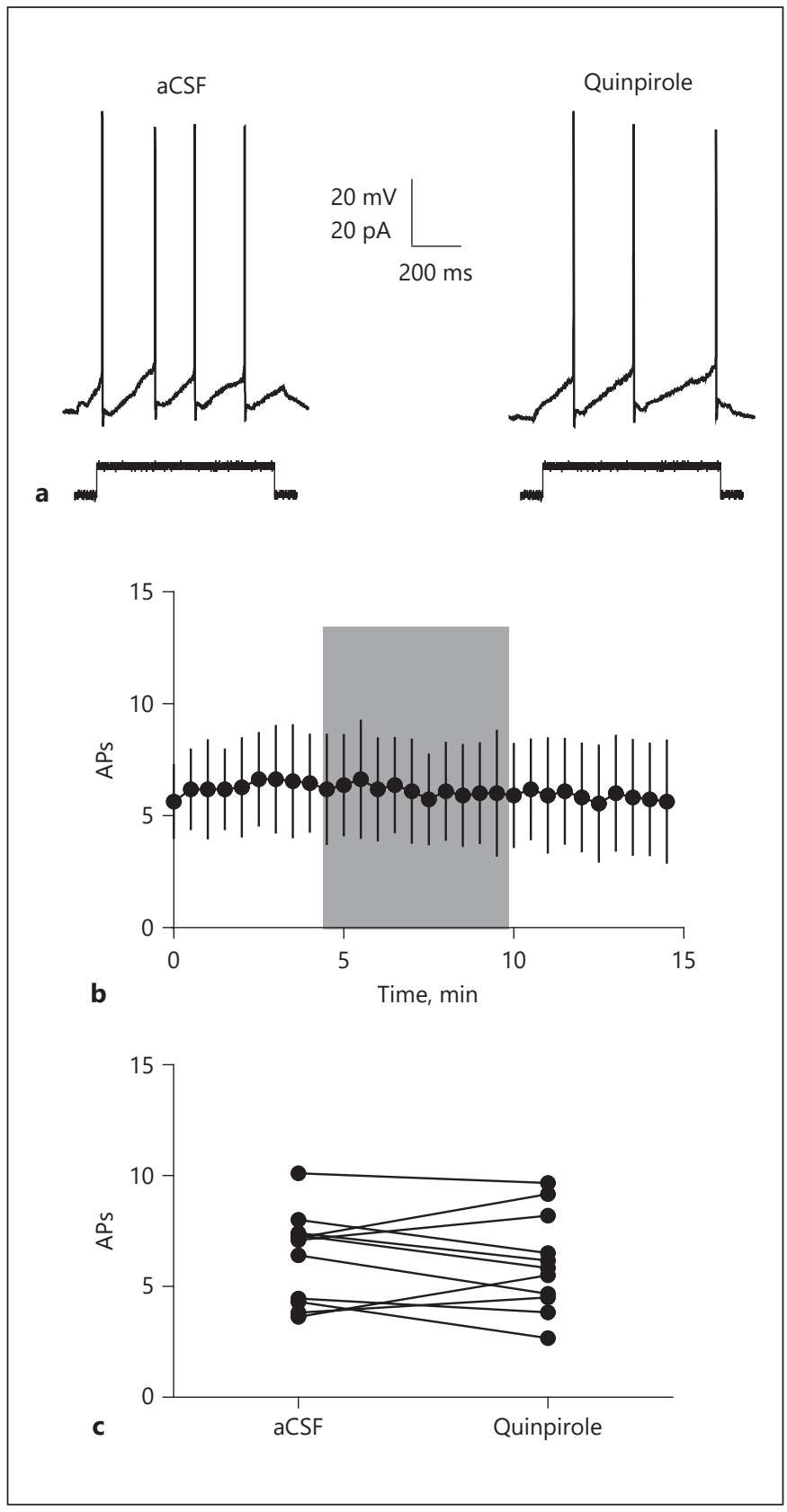

Fig. 3. Whole-cell patch clamp recordings from LTS interneurons in control medial prefrontal cortex show no consistent response to D2 agonists. a Representative recording of suprathreshold current injection response in LTS interneurons. $\mathbf{b}$ Time course of response to quinpirole (1-2 $\mu \mathrm{M})$ shows no change in AP count through drug administration. All data are mean \pm standard deviation. c Group data of average response ( 6 trials) to depolarizing current before and during quinpirole administration. AP, action potential; LTS, low threshold-spiking. 
high degree of variability in our measures, overall the data suggest that DN-DISC1 affects DA modulation of excitation-inhibition balance in the prefrontal circuits of mice.

FS interneurons were dramatically altered in $\mathrm{DN}$ DISC1 mice, necessitating post hoc staining with a reliable marker of PV interneurons (PNNs) prior to description of their physiological properties. The action potentials in this FS cell population were slower and the cells could not sustain prolonged rapid firing. These observations are consistent with the loss of PV observed in these mice and indicate a loss of functional capacity in this critical neuronal population. An interesting aspect of this model is that DN-DISC1 expression is driven by $\alpha$ CaMKII, expressed primarily in PYR. Thus, the deficits observed in FS interneurons are driven by the impact of DN-DISC1 on PYR function. As PYR constitute the primary source of glutamatergic innervation onto FS interneurons, it is conceivable that the FS interneuron deficits are driven by altered pyramidal inputs. As these experiments were conducted in adult mice, the normal developmental increase in excitatory projections to FS interneurons during adolescence [68] could be affected by DN-DISC1, a result observed after electroporation of the Disc1 L100P point mutant [69].

The modulation of FS interneurons by DA is also impaired in DN-DISC1 mice. While some neurons still showed an increase in firing in response to quinpirole, most FS interneurons failed to increase their firing. This observation is consistent with what has been found in many different animal manipulations that yielded abnormal interneuron activity in the PFC, such as the neonatal ventral hippocampal lesion model [64], rats treated in utero with methylazoxymethanol acetate $[14,70]$, and maternal immune activation [71], among others. These models disrupt the normal developmental trajectory of inhibitory circuits. FS interneurons are a highly vulnerable population, especially in the perinatal period, coincident with our disruption of DISC1 signaling. During this period, FS interneurons undergo NMDA-dependent development, linking dysfunction induced by DN-DISC1 in pyramidal cells to the manifestation in interneurons. Due to their high firing rate, immature FS interneurons are easily disturbed by the generation of pro-oxidant molecules [26]. Immature PNNs are less effective in preventing oxidative damage to FS interneurons [72]. Alterations in PNN labeling have also been identified in the PFC of patients with schizophrenia [73] and in animal models [74]. The spidery appearance of PNN structure in DNDISC1 mice indicates abnormalities either in the forma- tion or maintenance of these structures, which may also compromise their function. We have previously shown both reduced PV staining [43] and signs of increased oxidative stress in the PFC of DN-DISC1 mice accompanied by impairments in PFC-dependent cognitive and motivational paradigms [75]. Thus, structural changes in PFC circuitry in DN-DISC1 mice and other models can drive functional deficits.

The DN-DISC1 mutation did not affect adult action potential or intrinsic excitability phenotype of LTS interneurons. While the number of cells expressing somatostatin is reduced in the cortex of patients with schizophrenia, somatostatin is present in a large variety of interneurons in the mouse, of which LTS interneurons are only a subset. In contrast to FS interneurons, LTS interneurons are less excitable in the immature cortex and have a lower firing rate [76], which may be protective. We did not detect changes in the intrinsic excitability and action potential characteristics of the PYR in which DN-DISC1 is expressed. This raises the need for future studies to understand how DN-DISC1 expression in PYR results in the dysfunction of PV-expressing FS interneurons, but not somatostatin-expressing LTS interneurons.

The data indicate that FS interneurons are highly vulnerable to the deleterious impact of expression of a truncated Discl gene in PFC PYR. This vulnerability may be driven by the protracted developmental trajectory of FS interneurons. The loss of DA modulation in FS interneurons and the abnormal appearance of PNNs suggest altered functional properties in this critical neuronal population. As PV interneurons help synchronize the activity of cortical networks, their insufficient activation could underscore altered high-frequency oscillations and behaviors that depend on proper excitation-inhibition balance. Observing this alteration in DN-DISC1 mice suggests that the DISC1 truncation originally identified in a Scottish family [29] may contribute to their risk of schizophrenia by altering FS interneuron developmental trajectories.

\section{Acknowledgments}

This work was supported by the National Institutes of Health (grant number R01 MH057683 to P. O'Donnell). We would like to thank Ms. Kierra S. Stephens for her excellent technical assistance and Dr. Frank Margolis for advice on the experiments and the manuscript.
26

Mol Neuropsychiatry 2018;4:20-29 DOI: $10.1159 / 000488030$
Cardarelli/Martin/Jaaro-Peled/Sawa/ Powell/O’Donnell 


\section{Statement of Ethics}

The authors have no ethical conflicts to disclose.

\section{Disclosure Statement}

The authors have no conflicts of interest to report. The work was conducted while P. O'Donnell was a Professor at the University of Maryland School of Medicine. P. O'Donnell is currently an employee at Takeda Pharmaceuticals.

\section{References}

1 Moghaddam B, Javitt D: From revolution to evolution: the glutamate hypothesis of schizophrenia and its implication for treatment. Neuropsychopharmacology 2012;37:4-15.

2 Lewis DA, Moghaddam B: Cognitive dysfunction in schizophrenia: convergence of gamma-aminobutyric acid and glutamate alterations. Arch Neurol 2006;63:1372-1376.

3 Rotaru DC, Lewis DA, Gonzalez-Burgos G: The role of glutamatergic inputs onto parvalbumin-positive interneurons: relevance for schizophrenia. Rev Neurosci 2012;23:97-109.

-4 Akbarian S, Huntsman MM, Kim JJ, Tafazzoli A, Potkin SG, Bunney WE Jr, Jones EG: GABAA receptor subunit gene expression in human prefrontal cortex: comparison of schizophrenics and controls. Cereb Cortex 1995;5:550-560.

5 Benes FM, Khan Y, Vincent SL, Wickramasinghe R: Differences in the subregional and cellular distribution of GABAA receptor binding in the hippocampal formation of schizophrenic brain. Synapse 1996;22:338349.

6 Benes FM, Vincent SL, Marie A, Khan Y: Upregulation of GABAA receptor binding on neurons of the prefrontal cortex in schizophrenic subjects. Neuroscience 1996;75: 1021-1031.

7 Curley AA, Lewis DA: Cortical basket cell dysfunction in schizophrenia. J Physiol 2012; 590:715-724.

-8 Lewis DA, Fish KN, Arion D, Gonzalez-Burgos G: Perisomatic inhibition and cortical circuit dysfunction in schizophrenia. Curr Opin Neurobiol 2011;21:866-872.

-9 Moyer CE, Delevich KM, Fish KN, Asafu-Adjei JK, Sampson AR, Dorph-Petersen KA, Lewis DA, Sweet RA: Reduced glutamate decarboxylase 65 protein within primary auditory cortex inhibitory boutons in schizophrenia. Biol Psychiatry 2012;72:734-743.

10 Volk DW, Pierri JN, Fritschy JM, Auh S, Sampson AR, Lewis DA: Reciprocal alterations in pre- and postsynaptic inhibitory markers at chandelier cell inputs to pyramidal neurons in schizophrenia. Cereb Cortex 2002 12:1063-1070.

11 Thompson M, Weickert CS, Wyatt E, Webster MJ: Decreased glutamic acid decarboxylase(67) mRNA expression in multiple brain areas of patients with schizophrenia and mood disorders. J Psychiatr Res 2009;43:970977.
12 Fung SJ, Webster MJ, Sivagnanasundaram S, Duncan C, Elashoff M, Weickert CS: Expression of interneuron markers in the dorsolateral prefrontal cortex of the developing human and in schizophrenia. Am J Psychiatry 2010;167:1479-1488.

13 Lavin A, Moore HM, Grace AA: Prenatal disruption of neocortical development alters prefrontal cortical neuron responses to dopamine in adult rats. Neuropsychopharmacology 2005;30:1426-1435.

14 Lodge DJ, Grace AA: Gestational methylazoxymethanol acetate administration: a developmental disruption model of schizophrenia. Behav Brain Res 2009;204:306-312.

15 Gill KM, Grace AA: Corresponding decrease in neuronal markers signals progressive parvalbumin neuron loss in MAM schizophrenia model. Int J Neuropsychopharmacol 2014;17: 1609-1619.

16 Lipska BK, Jaskiw GE, Chrapusta S, Karoum F, Weinberger DR: Ibotenic acid lesion of the ventral hippocampus differentially affects dopamine and its metabolites in the nucleus accumbens and prefrontal cortex in the rat. Brain Res 1992;585:1-6.

17 Lipska BK, Jaskiw GE, Weinberger DR: Postpubertal emergence of hyperresponsiveness to stress and to amphetamine after neonatal excitotoxic hippocampal damage: a potential animal model of schizophrenia. Neuropsychopharmacology 1993;9:67-75.

18 Sams-Dodd F, Lipska BK, Weinberger DR: Neonatal lesions of the rat ventral hippocampus result in hyperlocomotion and deficits in social behaviour in adulthood. Psychopharmacology (Berl) 1997;132:303-310.

19 O’Donnell P, Lewis BL, Weinberger DR, Lipska BK: Neonatal hippocampal damage alters electrophysiological properties of prefrontal cortical neurons in adult rats. Cereb Cortex 2002;12:975-982.

20 Tseng KY, Lewis BL, Lipska BK, O’Donnell P: Post-pubertal disruption of medial prefrontal cortical dopamine-glutamate interactions in a developmental animal model of schizophrenia. Biol Psychiatry 2007;62:730-738.

21 Tseng KY, Chambers RA, Lipska BK: The neonatal ventral hippocampal lesion as a heuristic neurodevelopmental model of schizophrenia. Behav Brain Res 2009;204:295-305.
22 Homayoun H, Moghaddam B: NMDA receptor hypofunction produces opposite effects on prefrontal cortex interneurons and pyramidal neurons. J Neurosci 2007;27:1149611500.

23 Belforte JE, Zsiros V, Sklar ER, Jiang Z, Yu G, Li Y, Quinlan EM, Nakazawa K: Postnatal NMDA receptor ablation in corticolimbic interneurons confers schizophrenia-like phenotypes. Nat Neurosci 2010;13:76-83.

24 Nakazawa K, Zsiros V, Jiang Z, Nakao K, Kolata S, Zhang S, Belforte JE: GABAergic interneuron origin of schizophrenia pathophysiology. Neuropharmacology 2012;62:15741583.

-25 Cabungcal JH, Counotte DS, Lewis EM, Tejeda HA, Piantadosi P, Pollock C, Calhoon GG, Sullivan EM, Presgraves E, Kil J, Hong LE, Cuenod M, Do KQ, O’Donnell P: Juvenile antioxidant treatment prevents adult deficits in a developmental model of schizophrenia. Neuron 2014;83:1073-1084

26 Steullet P, Cabungcal JH, Monin A, Dwir D, O’Donnell P, Cuenod M, Do KQ: Redox dysregulation, neuroinflammation, and NMDA receptor hypofunction: a "central hub" in schizophrenia pathophysiology? Schizophr Res 2016;176:41-51.

27 O'Donnell P: Adolescent onset of cortical disinhibition in schizophrenia: insights from animal models. Schizophr Bull 2011;37:484-492.

28 Millar JK, Wilson-Annan JC, Anderson S, Christie S, Taylor MS, Semple CA, Devon RS, St Clair DM, Muir WJ, Blackwood DH, Porteous DJ: Disruption of two novel genes by a translocation co-segregating with schizophrenia. Hum Mol Genet 2000;9:1415-1423.

29 St Clair D, Blackwood D, Muir W, Carothers A, Walker M, Spowart G, Gosden C, Evans HJ: Association within a family of a balanced autosomal translocation with major mental illness. Lancet 1990;336:13-16.

30 Brandon NJ, Sawa A: Linking neurodevelopmental and synaptic theories of mental illness through DISC1. Nat Rev Neurosci 2011;12: 707-722.

- 31 Kim JY, Liu CY, Zhang F, Duan X, Wen Z, Song J, Feighery E, Lu B, Rujescu D, St Clair $\mathrm{D}$, Christian K, Callicott JH, Weinberger DR, Song H, Ming GL: Interplay between DISC1 and GABA signaling regulates neurogenesis in mice and risk for schizophrenia. Cell 2012; 148:1051-1064. 
-32 Zhou M, Li W, Huang S, Song J, Kim JY, Tian X, Kang E, Sano Y, Liu C, Balaji J, Wu S, Zhou Y, Zhou Y, Parivash SN, Ehninger D, He L, Song H, Ming GL, Silva AJ: mTOR inhibition ameliorates cognitive and affective deficits caused by Disc1 knockdown in adult-born dentate granule neurons. Neuron 2013;77: 647-654.

33 Greenhill SD, Juczewski K, de Haan AM, Seaton G, Fox K, Hardingham NR: NEURODEVELOPMENT. Adult cortical plasticity depends on an early postnatal critical period. Science 2015;349:424-427.

- 34 Tsuboi D, Kuroda K, Tanaka M, Namba T, Iizuka Y, Taya S, Shinoda T, Hikita T, Muraoka S, Iizuka M, Nimura A, Mizoguchi A, Shiina N, Sokabe M, Okano H, Mikoshiba K, Kaibuchi K: Disrupted-in-schizophrenia 1 regulates transport of ITPR1 mRNA for synaptic plasticity. Nat Neurosci 2015;18:698-707.

- 35 Su P, Li S, Chen S, Lipina TV, Wang M, Lai TK, Lee FH, Zhang H, Zhai D, Ferguson SS, Nobrega JN, Wong AH, Roder JC, Fletcher PJ, Liu F: A dopamine D2 receptor-DISC1 protein complex may contribute to antipsychotic-like effects. Neuron 2014;84:13021316.

- 36 Hayashi-Takagi A, Araki Y, Nakamura M, Vollrath B, Duron SG, Yan Z, Kasai H, Huganir RL, Campbell DA, Sawa A: PAKs inhibitors ameliorate schizophrenia-associated dendritic spine deterioration in vitro and in vivo during late adolescence. Proc Natl Acad Sci USA 2014;111:6461-6466.

- 37 Niwa M, Jaaro-Peled H, Tankou S, Seshadri S, Hikida T, Matsumoto Y, Cascella NG, Kano S, Ozaki N, Nabeshima T, Sawa A: Adolescent stress-induced epigenetic control of dopaminergic neurons via glucocorticoids. Science 2013;339:335-339.

- 38 Kamiya A, Kubo K, Tomoda T, Takaki M, Youn R, Ozeki Y, Sawamura N, Park U, Kudo C, Okawa M, Ross CA, Hatten ME, Nakajima $\mathrm{K}$, Sawa A: A schizophrenia-associated mutation of DISC1 perturbs cerebral cortex development. Nat Cell Biol 2005;7:1167-1178.

- 39 Holley SM, Wang EA, Cepeda C, Jentsch JD, Ross CA, Pletnikov MV, Levine MS: Frontal cortical synaptic communication is abnormal in Disc1 genetic mouse models of schizophrenia. Schizophr Res 2013;146:264-272.

40 Sauer JF, Struber M, Bartos M: Impaired fastspiking interneuron function in a genetic mouse model of depression. Elife 2015;4: 04979.

-41 Crabtree GW, Sun Z, Kvajo M, Broek JA, Fenelon K, McKellar H, Xiao L, Xu B, Bahn S, O’Donnell JM, Gogos JA: Alteration of neuronal excitability and short-term synaptic plasticity in the prefrontal cortex of a mouse model of mental illness. J Neurosci 2017;37: 4158-4180.

42 Maher BJ, LoTurco JJ: Disrupted-in-schizophrenia (DISC1) functions presynaptically at glutamatergic synapses. PLoS One 2012;7: e34053.
43 Hikida T, Jaaro-Peled H, Seshadri S, Oishi K, Hookway C, Kong S, Wu D, Xue R, Andrade M, Tankou S, Mori S, Gallagher M, Ishizuka K, Pletnikov M, Kida S, Sawa A: Dominantnegative DISC1 transgenic mice display schizophrenia-associated phenotypes detected by measures translatable to humans. Proc Natl Acad Sci USA 2007;104:14501-14506.

44 Tseng KY, O’Donnell P: Dopamine modulation of prefrontal cortical interneurons changes during adolescence. Cereb Cortex 2007; 17:1235-1240.

-45 Tseng KY, O’Donnell P: Dopamine-glutamate interactions controlling prefrontal cortical pyramidal cell excitability involve multiple signaling mechanisms. J Neurosci 2004; 24:5131-5139.

46 Tseng KY, Mallet N, Toreson KL, Le Moine C, Gonon F, O'Donnell P: Excitatory response of prefrontal cortical fast-spiking interneurons to ventral tegmental area stimulation in vivo. Synapse 2006;59:412-417.

47 Tseng KY, O’Donnell P: D2 dopamine receptors recruit a GABA component for their attenuation of excitatory synaptic transmission in the adult rat prefrontal cortex. Synapse 2007;61:843-850.

48 Cauli B, Audinat E, Lambolez B, Angulo MC, Ropert N, Tsuzuki K, Hestrin S, Rossier J: Molecular and physiological diversity of cortical nonpyramidal cells. J Neurosci 1997;17:38943906.

49 Petilla Interneuron Nomenclature Group, Ascoli GA, Alonso-Nanclares L, Anderson SA, Barrionuevo G, Benavides-Piccione R, Burkhalter A, Buzsaki G, Cauli B, Defelipe J, Fairen A, Feldmeyer D, Fishell G, Fregnac Y, Freund TF, Gardner D, Gardner EP, Goldberg JH, Helmstaedter M, Hestrin S, Karube F, Kisvarday ZF, Lambolez B, Lewis DA, Marin O, Markram H, Munoz A, Packer A, Petersen CC, Rockland KS, Rossier J, Rudy B, Somogyi P, Staiger JF, Tamas G, Thomson AM, Toledo-Rodriguez M, Wang Y, West DC, Yuste R: Petilla terminology: nomenclature of features of GABAergic interneurons of the cerebral cortex. Nat Rev Neurosci 2008;9: 557-568.

50 Kawaguchi Y, Kondo S: Parvalbumin, somatostatin and cholecystokinin as chemical markers for specific GABAergic interneuron types in the rat frontal cortex. J Neurocytol 2002;31:277-287.

51 Kawaguchi Y, Kubota Y: GABAergic cell subtypes and their synaptic connections in rat frontal cortex. Cereb Cortex 1997;7:476-486.

52 Pouille F, Scanziani M: Enforcement of temporal fidelity in pyramidal cells by somatic feed-forward inhibition. Science 2001;293: 1159-1163.

53 Pouille F, Marin-Burgin A, Adesnik H, Atallah BV, Scanziani M: Input normalization by global feedforward inhibition expands cortical dynamic range. Nat Neurosci 2009;12: 1577-1585.
54 Pouille F, Watkinson O, Scanziani M, Trevelyan AJ: The contribution of synaptic location to inhibitory gain control in pyramidal cells. Physiol Rep 2013; 1:e00067.

55 Sohal VS, Zhang F, Yizhar O, Deisseroth K: Parvalbumin neurons and gamma rhythms enhance cortical circuit performance. Nature 2009;459:698-702.

56 Cardin JA, Carlen M, Meletis K, Knoblich U, Zhang F, Deisseroth K, Tsai LH, Moore CI: Driving fast-spiking cells induces gamma rhythm and controls sensory responses. $\mathrm{Na}$ ture 2009;459:663-667.

57 Seamans JK, Gorelova N, Durstewitz D, Yang CR: Bidirectional dopamine modulation of GABAergic inhibition in prefrontal cortical pyramidal neurons. J Neurosci 2001;21:36283638.

58 Gorelova N, Seamans JK, Yang CR: Mechanisms of dopamine activation of fast-spiking interneurons that exert inhibition in rat prefrontal cortex. J Neurophysiol 2002;88:31503166.

59 Silberberg G, Markram H: Disynaptic inhibition between neocortical pyramidal cells mediated by Martinotti cells. Neuron 2007;53: 735-746.

60 Breton JD, Stuart GJ: Somatic and dendritic $\mathrm{GABA}(\mathrm{B})$ receptors regulate neuronal excitability via different mechanisms. J Neurophysiol 2012;108:2810-2818.

61 Lewis DA, Hashimoto T, Morris HM: Cell and receptor type-specific alterations in markers of GABA neurotransmission in the prefrontal cortex of subjects with schizophrenia. Neurotox Res 2008; 14:237-248.

62 Morris HM, Hashimoto T, Lewis DA: Alterations in somatostatin mRNA expression in the dorsolateral prefrontal cortex of subjects with schizophrenia or schizoaffective disorder. Cereb Cortex 2008;18:1575-1587.

-63 Hashimoto T, Arion D, Unger T, MaldonadoAviles JG, Morris HM, Volk DW, Mirnics K, Lewis DA: Alterations in GABA-related transcriptome in the dorsolateral prefrontal cortex of subjects with schizophrenia. Mol Psychiatry 2008; $13: 147-161$.

64 Tseng KY, Lewis BL, Hashimoto T, Sesack SR, Kloc M, Lewis DA, O’Donnell P: A neonatal ventral hippocampal lesion causes functional deficits in adult prefrontal cortical interneurons. J Neurosci 2008;28:12691-12699.

65 Niwa M, Kamiya A, Murai R, Kubo K, Gruber AJ, Tomita K, Lu L, Tomisato S, Jaaro-Peled H, Seshadri S, Hiyama H, Huang B, Kohda K, Noda Y, O'Donnell P, Nakajima K, Sawa A, Nabeshima T: Knockdown of DISC1 by in utero gene transfer disturbs postnatal dopaminergic maturation in the frontal cortex and leads to adult behavioral deficits. Neuron 2010;65:480-489.

66 Kawaguchi Y, Kubota Y: Correlation of physiological subgroupings of nonpyramidal cells with parvalbumin- and calbindinD28k-immunoreactive neurons in layer $\mathrm{V}$ of rat frontal cortex. J Neurophysiol 1993;70:387-396. 
67 Tateno T, Harsch A, Robinson HP: Threshold firing frequency-current relationships of neurons in rat somatosensory cortex: type 1 and type 2 dynamics. J Neurophysiol 2004;92: 2283-2294.

68 Caballero A, Flores-Barrera E, Cass DK, Tseng KY: Differential regulation of parvalbumin and calretinin interneurons in the prefrontal cortex during adolescence. Brain Struct Funct 2014;219:395-406.

69 Borkowska M, Millar JK, Price DJ: Altered Disrupted-in-Schizophrenia-1 function affects the development of cortical parvalbumin interneurons by an indirect mechanism. PLoS One 2016;11:e0156082.
70 Lodge DJ, Behrens MM, Grace AA: A loss of parvalbumin-containing interneurons is associated with diminished oscillatory activity in an animal model of schizophrenia. J Neurosci 2009;29:2344-2354.

1 Canetta S, Bolkan S, Padilla-Coreano N, Song LJ, Sahn R, Harrison NL, Gordon JA, Brown A, Kellendonk C: Maternal immune activation leads to selective functional deficits in offspring parvalbumin interneurons. Mol Psychiatry 2016;21:956-968.

72 Cabungcal JH, Steullet P, Morishita H, Kraftsik R, Cuenod M, Hensch TK, Do KQ: Perineuronal nets protect fast-spiking interneurons against oxidative stress. Proc Natl Acad Sci USA 2013;110:9130-9135.

-73 Enwright JF, Sanapala S, Foglio A, Berry R, Fish KN, Lewis DA: Reduced labeling of parvalbumin neurons and perineuronal nets in the dorsolateral prefrontal cortex of subjects with schizophrenia. Neuropsychopharmacology 2016;41:2206-2214.
74 Paylor JW, Lins BR, Greba Q, Moen N, de Moraes RS, Howland JG, Winship IR: Developmental disruption of perineuronal nets in the medial prefrontal cortex after maternal immune activation. Sci Rep 2016;6:37580.

75 Johnson AW, Jaaro-Peled H, Shahani N, Sedlak TW, Zoubovsky S, Burruss D, Emiliani F, Sawa A, Gallagher M: Cognitive and motivational deficits together with prefrontal oxidative stress in a mouse model for neuropsychiatric illness. Proc Natl Acad Sci USA 2013; 110:12462-12467.

76 Lazarus MS, Huang ZJ: Distinct maturation profiles of perisomatic and dendritic targeting GABAergic interneurons in the mouse primary visual cortex during the critical period of ocular dominance plasticity. J Neurophysiol 2011;106:775-787. 